\title{
Pengaruh Firm Size, Leverage, Profitabilitas dan Kebijkan Deviden terhadap Manajemen Laba:Studi Kasus Perusahaan Manufaktur yang Terdaftar di BEI Tahun 2016-2019
}

\author{
Dani Irfan Kamalita \\ Program Studi Magister Ilmu Manajemen, Pascasarjana, Universitas Islam Batik Surakarta \\ E-mail: daniirfank221@gmail.com
}

\begin{abstract}
Article Info
Article History

Received: 2021-11-20

Revised: 2021-12-15

Published: 2022-01-13

Keywords:

Company Size;

Benefit;

Profitability;

Dividend Policy;

Profit management.

Abstract

Income management practices in Indonesia are highly rated due to poor investor protection. Results are managed by executives and balance sheet teams because they expect profits. The purpose of this study is to jointly analyze the effect of firm size, debt, profitability and dividend policy. on earnings management in manufacturing companies listed on the Indonesia Stock Exchange for the period 2016 - 2019. Sampling used an unknown sampling technique, namely intentional sampling with a sample of 23 companies with an investigation period of 4 years. Multiple linear regression hypothesis testing using the IBM SPSS Statistics Program version 23 method. The results of this study indicate that firm size with a t value of 0.336 and a significance level of $0.038(<0>0.05)$ has a significant effect on earnings management. With a t-count value of 0.587 , profitability has no effect on earnings management and has a significance level of $0.560(>00.05)$. With a count of 0.065 and a significance level of 0.048 (ylt; 0.05), dividend policy has a significant effect on earnings management. Company size, leverage, profitability and dividend policy as a whole have a significant effect on earnings management with a significance value of 0.024 (ylt; $0,05)$.
\end{abstract}

\begin{tabular}{l}
\hline Artikel Info \\
\hline Sejarah Artikel \\
Diterima: 2021-11-20 \\
Direvisi: 2021-12-15 \\
Dipublikasi: 2022-01-13
\end{tabular}

Kata kunci:

Ukuran Perusahaan; Leverage;

Profitabilitas; Kebijakan Dividen; Manajemen Laba.

\section{PENDAHULUAN}

Laporan keuangan tahunan perusahaan, laba merupakan salah satu potensi informasi yang sangat penting baik bagi pihak internal perusahaan maupun kepada pihak eksternal. Laba perusahaan yang dihasilkan dari usahanya merupakan ukuran kinerja perusahaan Perusahaan. Akuntansi berbasis akrual memiliki kelemahan yaitu memberikan kebebasan kepada manajer untuk memilih metode akuntansi yang dibutuhkan perusahaan, selama metode akuntansi tersebut tidak menyimpang dari standar akuntansi keuangan yang berlaku. Dalam kondisi ini, ada satu kondisi, jika manajemen tidak dapat mencapai target laba yang diinginkan, maka manajemen akan mendapatkan keuntungan dari fleksibilitas yang memungkinkan standar akuntansi dalam penyusunan laporan keuangan untuk mengubah hasil yang dilaporkan. Metode akuntansi yang sengaja dipilih oleh manajemen untuk tujuan tertentu dikenal sebagai manajemen laba. Manajemen laba atau profit management menurut Purnama, (2017) adalah suatu metode yang digunakan manajemen untuk mengelola laporan keuangan tahunan perusahaan dengan memilih metode akuntansi tertentu, dengan tujuan untuk meningkatkan laba bersih dan goodwill sesuai dengan harapan manajemen. 
Manajemen laba dilakukan oleh manajer dan tim yang menyusun laporan keuangan karena mengharapkan keuntungan dari tindakan tersebut.

Praktik manajemen pendapatan di Indonesia dinilai tinggi karena perlindungan investor yang buruk. Fenomena di Indonesia menunjukkan bahwa manajemen laba terjadi di perusahaan besar, seperti yang terjadi di PT Waskita Karya pada tahun 2016. Kasus pengelolaan laba yang oportunistik dan kecenderungan manipulasi laporan keuangan PT Waskita Karya tahun 2016 mengakibatkan defisit modal sebesar Rp. 457 miliar (Prasadhita, 2017). Pada tahun 2015 terjadi kasus manajemen laba dengan produsen elektronik asal Jepang yaitu PT Toshiba. Panitia independen yang ditunjuk PT Toshiba menyebutkan PT Toshiba telah meningkatkan pendapatan hingga USD16 miliar (Dewi dan Wirawati, 2019).Salah satu kasus manajemen laba yang terjadi di Indonesia adalah kasus perusahaan PT. Inovisi Infracom tahun 2015 (Panjaitan dan Muslih, 2019). Menurut Purnama (2017), beberapa faktor yang mempengaruhi manajemen laba antara lain: profitabilitas, hutang, ukuran perusahaan, kepemilikan institusional dan struktur kepemilikan. Sedangkan penelitian Hasty dan Herawaty (2017) menyebutkan beberapa faktor yang mempengaruhi manajemen laba, yaitu: struktur kepemilikan, hutang, profitabilitas dan kebijakan dividen, profitabilitas, struktur kepemilikan dan kebijakan dividen.

Manajemen laba dipengaruhi oleh beberapa faktor, antara lain ukuran perusahaan (company size). Ukuran perusahaan merupakan nilai yang menunjukkan besar kecilnya perusahaan. Menurut Rusdiyanto dan Narsa, ukuran perusahaan berhubungan negatif dengan pengelolaan hasil, (2020) bahwa perusahaan Hal ini disebabkan karena perusahaan besar lebih banyak dikritik oleh pemegang saham dan pemangku kepentingan eksternal, memberikan tekanan lebih pada perusahaan besar untuk menghasilkan laporan keuangan yang dapat diprediksi. Faktor lain yang mempengaruhi manajemen hasil adalah leverage (Amidreza dan Mortazavi, 2016), hutang yang digunakan perusahaan untuk mendanai asetnya untuk menjalankan bisnisnya. Leverage diukur dengan membandingkan total hutang dengan total aset. Menurut Yudiastuti dan Wirasedana (2018), Leverage Index merupakan indeks yang menggambarkan proporsi total aset yang telah dipinjamkan kreditur kepada perusahaan. Faktor berikutnya yang mempengaruhi hasil manajemen adalah profitabilitas. Profitab- ilitas adalah kemampuan perusahaan untuk mendapatkan keuntungan dari mengoperasikan asetnya. Jika tidak ada laba, perusahaan akan kesulitan menarik modal asing (Hasty dan Herawaty, 2017). Manajemen erat kaitannya dengan keuntungan keseluruhan suatu perusahaan.Metrik profitabilitas lebih menarik bagi investor saat membuat keputusan investasi. Investor lebih cenderung berinvestasi di perusahaan dengan pengembalian tinggi daripada di perusahaan dengan pengembalian rendah. Manfaat yang maksimal (Agustia dan Suryani, 2018). Menurut penelitian Hasti dan Herawaty (2017), mereka mengkonfirmasi bahwa profitabilitas mempengaruhi manajemen hasil, semakin tinggi profitabilitas, semakin baik perusahaan, karena profitabilitas dapat menghasilkan laba yang tinggi pada asetnya.

Faktor terakhir adalah kebijakan deviden Kebijakan deviden merupakan keputusan apakah laba perusahaan yang dihasilkan pada akhir tahun akan dibagikan kepada pemegang saham dalam bentuk deviden atau untuk menambah modal untuk pembayaran investasi di masa yang akan datang. Jika lebih mungkin daripada laba ditahan (Dahayani, et al, 2017) Manajemen mencapai tujuan untuk mengurangi jumlah dividen yang harus dibayarkan, maka manajemen, yang memiliki lebih banyak informasi daripada pemegang saham dapat mengelola laba, memiliki laba yang dilaporkan (Wen Dia dkk., 2017). Kebijakan dividen merupakan salah satu motivasi bagi manajer untuk melakukan manajemen laba dengan pola pengurangan laba. Penelitian oleh Wen He et al., (2017) menunjukkan bahwa kebijakan dividen berhubungan negatif dengan praktik manajemen laba perusahaan.

Tindakan manajemen laba dapat terjadi pada perusahaan manufaktur atau industri. Kasus manajemen laba tersebut tentunya akan menimbulkan kerugian bagi perusahaan dan dapat menurunkan kepercayaan masyarakat khususnya investor. Banyaknya kasus manajemen laba dalam pelaporan akuntansi perusahaan di Indonesia menjadi dasar bagi banyak penelitian tentang manajemen laba. Berbagai hasil penelitian tentang manajemen hasil di Indonesia juga sangat beragam dan menarik untuk diulas. Hal ini memotivasi peneliti untuk memajukan penelitian tentang manipulasi laba di bidang manufaktur melalui penelitian yang berjudul "Pengaruh Ukuran Perusahaan, Hutang, Profitabilitas dan Kebijakan Investasi. Dividen dalam Manajemen Laba (Studi Kasus Perusahaan Manufaktur Tercatat 2016-2019)". 


\section{METODE PENELITIAN}

Penelitian ini adalah metode deskriptif kuantitatif untuk menganalisis pengaruh ukuran perusahaan, hutang, profitabilitas dan kebijakan dividen terhadap manajemen laba pada perusahaan manufaktur yang terdaftar di Bursa Efek Indonesia periode 2016-2019. Jenis data yang digunakan adalah data kuantitatif, yang dinyatakan dalam angka-angka yang menunjukkan nilai variabel. Sumber data yang digunakan dalam penelitian ini adalah data sekunder dari Statistik Bulanan BEI yang terdaftar di Bursa Efek Indonesia tahun 2016-2019. Populasi yang digunakan adalah seluruh perusahaan manufaktur yang terdaftar di Bursa Efek Indonesia (BEI) dari tahun 2016 sampai dengan tahun 2019. Sampel untuk penelitian ini adalah perusahaan yang bergerak di bidang manufaktur sebanyak 23 perusahaan dan dikalikan 4 tahun dengan sampel 92. Metode pengambilan sampel yang digunakan adalah non-likelihood sample; $\mathrm{H}$. pengambilan sampel yang disengaja, d. $H$. pemilihan sampel tidak acak, tetapi menggunakan pertimbangan dan kriteria tertentu yang ditetapkan oleh peneliti. Sebelum analisis regresi linier berganda dapat dilakukan dengan program SPSS Versi 23, terlebih dahulu dilakukan pengujian asumsi klasik: Uji analisis hipote-sis dilakukan dengan uji F, uji t dan uji R2.

\section{HASIL DAN PEMBAHASAN}

Berikut disampaikan beberapa analisa data untuk memperoleh hasil dalam pelaksanaan penelitian ini:

\section{Uji Normalitas}

Hasil uji normalitas menunjukkan bahwa variabel dependen Kolmogrov-smirnov Z sebesar 0,611 dengan tingkat signifikan sebesar $0,850>0,05$. Dari hasil tersebut dapat dilihat bahwa angka signifikan (Sig) untuk variabel dependen dan independen pada uji Kolmogrov-Smirnov lebih besar dari tingkat alpha $\alpha$ yang ditetapkan yaitu 0,05 pada tingkat kepercayaan 95\% yang berarti sampel terdistribusi secara normal dan tidak mengalami masalah normalitas.

\section{Uji Multikolinearitas}

Berdasarkan hasil uji ini diketahui bahwa Nilai tolerance Firm Size sebesar 0,872 dan Nilai VIF sebesar 1,1147. Nilai Leverage menunjukkan hasil perhitungan tolerance sebesar 0,904 dan nilai VIF sebesar 1,106. Nilai tolerance Profitabilitas sebesar 0,846 dan Nilai VIF sebesar 1,181. Nilai tolerance Kebijakan Deviden sebesar 0,180 dan Nilai
VIF sebesar 5,554. Dari hasil diatas diperoleh kesimpulan bahwa seluruh nilai VIF disemua variabel penelitian lebih kecil dari 10 dan nilai tolerance lebih dari 0,1. Hal ini menunjukkan bahwa tidak terdapat korelasi antara variabel bebas atau tidak terjadi masalah multikolinieritas diantara variabel inde- penden dalam model regresi.

\section{Pengujian Heteroskedastisitas}

Pada uji ini diketahui bahwa tidak ada satupun variabel independen yang signifikan secara statistik mempengaruhi variabel dependen abs_res (nilai absolut residual). Hal ini terlihat dari probabilitas signifikansi di atas tingkat kepercayaan $5 \%$ atau 0,05 . Dengan demikian, model regresi dalam penelitian ini tidak mengandung adanya heteroskedastisitas.

\section{Uji Auto Korelasi}

Dari tabel diatas menunjukkan bahwa nilai DW test sebesar 1,158. Nilai ini dibandingkan dengan nilai tabel menggunakan derajat keyakinan $95 \%$ dan a $=5 \%$ dengan jumlah sampel sebanyak 92 sampel serta jumlah variabel independen sebanyak 4, maka tabel durbin watson akan didapat nilai dL sebesar 1,5713, dU sebesar 1,7523. Dapat disimpulkan nilai DW test sebesar 1,58 lebih kecil dari dU sebesar 1,7523. Diperoleh kesimpulan bahwa $\mathrm{dW}<\mathrm{dL}$ atau 1,158 $<1,7523$. Jadi tidak terjadi autokorelasi yang bersifat positif mendukung terhindarnya autokorelasi pada model yang digunakan dalam penelitian ini.

\section{Uji Regresi Linier Berganda}

Berdasarkan pengujian diperoleh persamaan regresi linear berganda sebagai berikut:

$\mathrm{Y}=0,395+0,005 \mathrm{X} 1+(-0,120) \mathrm{X} 2+(-0,311) \mathrm{X} 3+$ $0,012 \mathrm{X} 4+\mathrm{e}$

Keterangan:

$\mathrm{Y}=$ Manajemen laba

$\mathrm{X} 1=$ Firm Size

$\mathrm{X} 2$ = Leverage

$\mathrm{X} 3$ = Profitabilitas

$\mathrm{X} 4=$ Kebijakan Dividen

$\beta 0=$ Konstanta

$\mathrm{e} \quad=$ error

Persamaan regresi diatas dapat diinterpretasikan bahwa konstanta $=0,395$ artinya apabila variabel firm size (X1), leverage (X2), profitabilitas (X3) dan kebijakan dividen (X4) bernilai nol (0) atau konstan maka manajemen laba (Y) adalah sebesar 0,395. Koefisien variabel firm size (X1) menunjukkan angka 0,005, yang lebih kecil $\alpha=0,05(0,005<0,05)$. 
Sehingga firm size berpengaruh positif dan signifikan terhadap manajemen laba. firm size yang semakin tinggi atau besar cenderung meningkatkan manajemen laba. Koefisien variabel Leverage (X2) menunjukkan angka $0,120(>0,05)$, yang artinya Leverage berpengaruh negatif dan tidak signifikan terhadap manajemen laba. Koefisien variabel profitabilitas (X3) menunjukkan angka $-0,311(>0,05)$, yang artinya profitabilitas berpengaruh negatif dan tidak signifikan terhadap manajemen laba. Koefisien variabel kebijakan dividen (X4) menunjukkan angka 0,012 $(<0,05)$. Artinya bahwa kebijakan dividen berpengaruh signifikan terhadap manajemen laba.

\section{Uji Signifikansi Simultan (Uji F)}

Hasil pengujian simultan (uji F) menunjukkan nilai signifikansi sebesar 0,024 nilai tersebut di bawah nilai alpha $(\alpha=0,05)$. Kondisi tersebut menunjukkan bahwa firm size, leverage, profitabilitas dan kebijakan dividen secara bersama-sama berpengaruh secara signifikan terhadap variabel dependen manajemen laba. Hasil penelitian tersebut mendukung hasil penelitian oleh Yofi dan Elly, (2018) yang menunjukkan bahwa secara simultan Ukuran Perusahaan, Umur Perusahaan, Leverage, dan Profitabilitas berpengaruh signifikan terhadap Manajemen Laba. Hasil penelitian (Hasty dkk, 2017) menegaskan bahwa variabel independen (profitabilitas, kepemilikan manajerial, leverage, dan kebijakan dividen) mempengaruhi manajemen laba.

7. Uji Signifikansi Parameter Individual (Uji t). Berdasarkan, hasil uji $t$ dapat diinterpretasikan sebagai berikut:

a) Variabel firm size memiliki thitung sebesar 0,336 dan memiliki tingkat signifikansi 0,038 , yang lebih kecil dari alpha 0,05 $(0,038<0,05)$. Hasil tersebut menunjukkan bahwa firm size memiliki pengaruh signifikan terhadap manajemen laba sehingga hipotesis pertama (H1) yang menyatakan firm size berpengaruh positif signifikan terhadap manajemen laba, diterima.

b) Variabel leverage memiliki thitung sebesar $-2,489$ dan memiliki tingkat signifikansi 0,615 , yang lebih besar dari alpha 0,05 $(0,615>0,05)$. Hasil tersebut menunjukkan bahwa leverage tidak berpengaruh terhadap manajemen laba sehingga hipotesis kedua (H2) yang menyatakan leverage berpengaruh positif signifikan terhadap manajemen laba, ditolak.

c) Variabel profitabilitas memiliki thitung sebesar -0,587 dan memiliki tingkat signifikansi 0,560, yang lebih besar dari alpha $0,05(0,560>0,05)$. Hasil tersebut menunjukkan bahwa profitabilitas tidak berpengaruh terhadap manajemen laba. Sehingga hipotesis ketiga (H3) yang menyatakan profitabilitas berpengaruh positif signifikan terhadap manajemen laba, ditolak.

d) Variabel kebijakan deviden memiliki thitung sebesar 0,065 dan memiliki tingkat signifikansi 0,048, yang lebih kecil dari alpha $0,05(0,048<0,05)$. Hasil tersebut menunjukkan bahwa kebijakan deviden memiliki pengaruh positif dan signifikan terhadap manajemen laba. Sehingga hipotesis keempata (H4) yang menyatakan kebijakan deviden berpengaruh positif signifikan terhadap manajemen laba, diterima.

8. Hasil Uji Koefisien Determinan (R2).

Berdasarkan uji ini, nilai adjusted R2 sebesar 0,416. Hal ini berarti $41,6 \%$ variabel manajemen laba dipengaruhi oleh variabel meliputi firm size, leverage, profitabilitas dan kebijakan dividen, sedangkan 58,4\% sisanya dipengaruhi oleh faktor lain diluar model penelitian ini. Standard error of the estimate dalam penelitian ini sebesar 0,08923 , semakin kecil nilai tersebut maka menunjukkan semakin baik model regresi dalam memprediksi variabel dependen.

\section{SIMPULAN DAN SARAN}

\section{A. Simpulan}

Berdasarkan uraian analisis dan pembahasan penelitian ini, maka dapat disimpulkan bahwa:

1. Firm size berpengaruh signifikan terhadap manajemen laba, dengan nilai thitung sebesar 0,336 dan memiliki tingkat signifikansi 0,038 , yang lebih kecil dari alpha $0,05(0,038<0,05)$.

2. Leverage tidak berpengaruh terhadap manajemen laba, dengan nilai thitung sebesar -2,489 dan memiliki tingkat signifikansi 0,615 , yang lebih besar dari alpha $0,05(0,615>0,05)$.

3. Profitabilitas tidak berpengaruh terhadap manajemen laba, dengan nilai thitung sebesar -0,587 dan memiliki tingkat signifikansi 0,560, yang lebih besar dari alpha $0,05(0,560>0,05)$. 
4. Kebiajkan dividen berpengaruh signifikan terhadap manajemen laba, denganj nilai thitung sebesar 0,065 dan memiliki tingkat signifikansi 0,048, yang lebih kecil dari alpha $0,05(0,048<0,05)$.

5. Firm size, leverage, profitabilitas, dan kebijakan dividen secara bersama-sama berpengaruh signifikan terhadap manajemen laba, dengan nilai nilai signifikansi sebesar 0,024 nilai tersebut di bawah nilai alpha $(\alpha=0,05)$.

\section{B. Saran}

Beberapa saran yang dapat disampaikan dalam penelitian ini diantaranya:

1. Peneliti selanjutnya diharapkan dapat melakukan penelitian pada perusahaan yang terdaftar di BEI yang bergerak dalam bidang usaha yang lebih luas dan tidak terbatas pada sektor manufaktur saja sesuai dengan kondisi yang dihadapi pada saat itu.

2. Jumlah tahun penelitian bisa diperpanjang untuk tahun kebelakang dan tahun kedepan (terbaru) sehingga lebih menggambarkan praktek manajemen laba yang ada di Indonesia.

3. Untuk penelitian selanjutnya yang ingin melakukan kajian ulang terhadap penelitian ini disarankan untuk menambah atau mengganti variabel lain.

4. Menambah sumber-sumber informasi pengungkapan lainnya. Sehingga lebih dapat menggambarkan kondisi perusahaan. Seperti laporan-laporan lainnya yang dikeluarkan oleh perusahaan, koran, majalah, dan informasi lainnya.

\section{DAFTAR RUJUKAN}

Abbadi, Sinan S., Abuaddous, Murad Y., Bataineh, Hanady T \& Muttairi, Abdulla,. 2020. The Impact of Earnings Management on Dividend Policy: Evidence from Kuwait. International Journal of Financial Research Vol.11, No.5; 2020.

Agustia, Yofi Prima dan Suryani, Elly. 2018. Pengaruh Ukuran Perusahaan, Umur Perusahaan, Leverage, dan Profitabilitas Terhadap Manajemen Laba (Studi Pada Perusahaan Pertambangan yang Terdaftar di Bursa Efek Indonesia Periode 20142016). Jurnal ASET (Akuntansi Riset) Vol.10 No.1, 63-74.
Amertha, Indra Satya Prasavita., Ulupui, I Gusti Ketut Agung., dan Putri, I Gusti Ayu Made Asri Dwija. 2014. Analysis of firm size, leverage, corporate governance on earnings management practices (Indonesian evidence). Journal of Economics, Business, and Accountancy Ventura Vol.17, No.2, August 2014, pages $259-268$.

Amidreza, V., \& Mortazavi, M. S. S. 2016. The Impact of Financial Leverage on AccrualBased and Real Earnings Management. International Journal of Academic Research in Accounting, Finance and Management Sciences, 6(2), 53-60.

Asim, Aysha. 2018. Impact of Leverage on Earning Management Empirical Evidence from Manufacturing Sector of Pakistan. Historical Research Letter www.iiste.org Vol.46, 2018.

Dahayani, Ni Ketut Sri., I Ketut Budiartha, dan I Made Sadha Suardikha. (2017). Pengaruh Kebijakan Dividen Pada Manajemen Laba Dengan Good Corporate Governance Sebagai Moderasi. E-Jurnal Ekonomi dan Bisnis Universitas Udayana Vol.6 No.4.

Dewi, Putu Elsa Pratiwi dan Wirawati, Ni Gusti Putu. 2019. Pengaruh Leverage Terhadap Manajemen Laba Dengan Corporate Governance Sebagai Variabel Pemoderasi. E-Jurnal Akuntansi Universitas Udayana Vol.27.1.April (2019). ISSN: 2302-8556 505-533

DOI: https://doi.org/10.24843/EJA.2019.v27.i0 1.p19.

Halviani, Made Dwi dan Sisdyani, Eka Ardhani. 2014. Pengaruh Moderasi GCG pada Return on Asset dan Dividend Payout Ratio. EJurnal Akuntansi Universitas Udayana. Vol 7. 2: 332-34.

Hasty, Ayu Dwi dan Herawaty, Vinola. 2017. Pengaruh Struktur Kepemilikan, Leverage, Profitabilitas dan Kebijakan Dividen. Jurnal Media Riset Akuntansi, Auditing \& Informasi Vol.17 No.1 April 2017.

Nalarreason, Kadek Marlina., Sutrisno T dan Endang Mardiati. 2019. Impact of Leverage and Firm Size on Earnings Management in Indonesia. International Journal of Multicultural and Multireligious 
Understanding Vol.6, Issue.1 February, 2019 Pages: 19-24 http://ijmmu.com editor@ijmmu.com.

Panda, Brahmadev and Leepsa, N. M. 2017. Agency theory: Review of Theory and Evidence on Problems and Perspectives. Indian Journal of Corporate Governance 10(1) 74-95.

Panjaitan, Desri Kristianti \& Muslih, Muhamad. 2019. Manajemen Laba: Ukuran Perusahaan, Kepemilikan Manajerial dan Kompensasi Bonus. JURNAL ASET (AKUNTANSI RISET), 11 (1), 2019, 1-201| Jurnal ASET (Akuntansi Riset)Vol.11| No.1| 2019.

Prasadhita, Chandra. 2017. Pengaruh Profitabiltas Terhadap Manajemen Laba Perusahaan consumer Goods Yang Terdaftar di Bursa Efek Indonesia. Jurnal Riset Akuntansi Terpadu Vol.10 No.2, Oktober 2017 Hal. 247 - 256.

Purnama, Dendi. 2017. Analisis Pengaruh Profitabilitas, Leverage, Ukuran Perusahaan, Kepemilikan Institusional dan Kepemilikan Manajerial Terhadap Manajemen Laba. JRKA Vol.3 Isue.1, Februari 2017: 1 - 14.
Rusdiyanto dan Narsa, I Made. 2020. The Effect of Company Size, Leverage and Return on Asset on Earnings Management: Case Study Indonesian. Journal Espacios Vol. 41 (Issue 17).

Suprianto, Edy dan Setiawan, Doddy. 2014. Manajemen Laba di Indonesia: Studi Sebuah Bibliography. Jurnal Keuangan dan Perbankan, 21(2): 287-301, 2017 Nationally Accredited: No.040/P/2014 http://jurnal.unmer.ac.id/index.php/jkdp

Wen He, Lilian Ngb, Nataliya Zaiatsc dan Bohui Zhang. 2017. Dividend policy and earnings management across countries. Journal of Corporate Finance 4(2) (2017) 267-286.

Yamaditya, Vanian. 2014. Pengaruh Asimetri Informasi, Leverage dan Ukuran Perusahaan Terhadap Manajemen Laba (Studi Empiris pada Perusahaan Manufaktur yang Terdaftar di BEI Periode 2011-2013). Skripsi. Fakultas Ekonomika dan Bisnis Universitas Diponogoro.

Yudiastuti \& Wirasedana, L. N. 2018. Good Corporate Governance Memoderasi Pengaruh Leverage Terhadap Manajemen Laba. E-Jurnal Akuntansi Universitas Udayana, 23(1), 130-155. 